\title{
Advocacy as medical responsibility
}

I $\mathrm{n}$ his weekly paper, Die Medizinische Reform, Rudolf Virchow termed physicians "natural attorneys of the poor." In lay terms, advocacy involves an entity of greater power (which physicians with wealth, education and status represent) speaking out for one with lesser power, often for social justice. It's now a time-honoured role for physicians around the globe, including Canada. In 1996, the Royal College of Physicians and Surgeons of Canada recognized "Advocate" as one of seven essential physician roles. And in 2001, the Association of Faculties of Medicine of Canada adopted a social accountability vision. Advocacy efforts may promote the health of individuals, communities or populations, to incorporate broader health promotion activities on equity and socioeconomic issues including advocating changes in areas that affect patients directly, such as housing conditions or domestic violence. ${ }^{1}$

Health advocacy for peace and environmental issues, aimed at promoting broader determinants of population health, is also widely respected. Henri Dunant won the first Nobel Peace Prize, not just for founding the Red Cross as a humanitarian assistance organization, but also for lobbying to codify rights of combatants in war. Swiss physician Albert Schweitzer, renowned for humanitarian work in Lambaréné hospital in Gabon, used the prestige of his Nobel Peace Prize to publicly oppose "experts" who declared radiation effects of aboveground nuclear weapons testing to be negligible. American Cardiologist Bernard Lown, inventor of the defibrillator, joined his Soviet colleague Yevgeni Chazov, to cofound the International Physicians for the Prevention of Nuclear War (IPPNW). Together they mobilized physicians across the globe calling for the abolition of nuclear weapons, a potential cause of sudden planetary death, winning the Nobel Peace Prize in 1985.

Sometimes speaking out has a price. Dunant died in poverty; Schweitzer was ridiculed and Lown was labelled a Soviet sympathizer. In Canada, it took years for

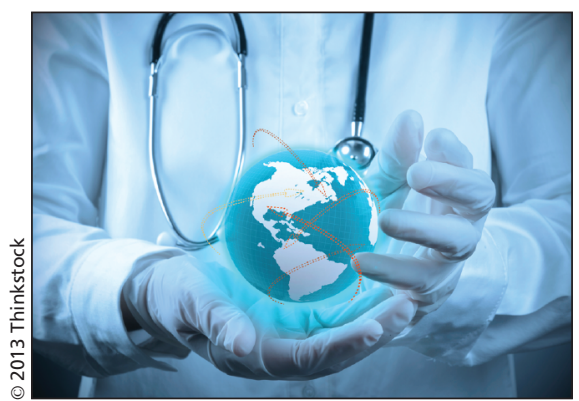

Dr. John O'Connor to clear his name after he questioned whether increased rates of cholangiocarcinoma among his Aboriginal patients in Fort Chipewyan, Alberta, might be related to high levels of arsenic and polycyclic aromatic hydrocarbons coming from the nearby tarsands project. $^{2}$

And those in the employ of government may not feel free to speak out. David Swann, was fired from his role as Medical Officer of Health for the Palliser Health region in Alberta for endorsing the Kyoto accord as a health protection and promotion measure.

Those who sought radical change in medicine, from Ignaz Semmelweis to John Snow to Rudolf Virchow, were regarded as troublemakers in their lifetimes, much as the Gandhis, Mandelas and Martin Luther Kings of yesteryear were reviled by those in authority. Indeed Virchow declared the essential nature of political work for health since Politik ist weiter nichts als Medizin im Grossen. The tradition of Latin American social medicine produced a Chilean president, public health physician Salvador Allende. Some physicians go further in their solidarity activities: Norman Bethune worked as an army surgeon in China and Che Guevara organized armed forces throughout Latin America.

Yet sticking to peaceful means, avoiding politics, merely fulfilling professional obligations is no guarantee of safety. In Nepal, physicians who were imprisoned for caring for protesters beaten by Royalist government forces, were only released after international medical activism, ${ }^{3}$ Later, these doctors occupied leadership roles in the newly democratized country. Closer to home, Canadian practitioners who cared for refugees who protested government cutbacks to health coverage for their patients, were condemned as "extremist" by federal ministers. To adapt the famous observation of Brazilian archbishop Dom Helder Camara: ${ }^{4}$ When I give treatment to the poor, they call me a saint. When I ask why the poor are untreated, they call me a communist.

We will not always agree on issues for which we advocate. Many challenges to physician advocacy remain. Though essential for the training of physicians, we have no standardized curricula or agreed upon competencies. Society may not recognize the benefits of supporting advocacy, sometimes for opposing causes. Ideally, physicians would cede our role as advocates in favour of empowering those who are marginalized to find their own voices.

However, until such time as decisionmakers hear the voices of the vulnerable, advocacy, with its inherent risks, remains the responsibility of all physicians. Remember the immortal words of pastor Martin Niemöller, "First they came for the Socialists ... then they came for the Jews ... then they came for me, and no one was left to speak for me."

\section{Neil Arya MD}

Department of Family Medicine

McMaster University

Hamilton, Ont.

\section{References}

1. Gruen RL, Pearson SD, Brennan TD. Physiciancitizens - public roles and professional obligations. JAMA 2004;291:94-8.

2. Lanktree. G. Oilsands whistleblower MD cleared Government charge of "undue alarm" from cancer warning remains. National Review of Medicine. 2008:5.

3. Singh S. Arya N. Mills E. et al. Free doctors and medical students detained in Nepal. Lancet 2006; 367:1730.

4. Lecumberri B. Brazil's Helder Camara, champion of poor, dies at 90. Agence France Presse 1999 Aug. 28.

Acknowledgements: Kathleen Huth, Josephine McMurray, Joanna Santa Barbara, Warren Bell, Andrew Pinto and Lisa Mu provided invaluable editorial advice.

CMAJ 2013. DOI:10.1503/cmaj.130649

All editorial matter in CMAJ represents the opinions of the authors and not necessarily those of the Canadian Medical Association. 